accord with the view that longer preregistration training would exacerbate the problems house officers face..$^{21}$ Less than a quarter of respondents would encourage potential medical students to enter the profession, although over half would recommend their job to a friend.

\section{CONCLUSION}

There are serious deficiencies in the preparation of house officers for their role and in the education they receive in post. They are often subject to excessive and inappropriate demands, working rotas incompatible with NHS Management Executive targets in hospitals that many of them regard as insecure. Unsurprisingly, few house officers would encourage others to take up medicine.

We thank the house officers who completed our questionnaire; the clinical tutors and their staff who distributed it; Professors John Anderson and Peter Flute and Drs Trevor Bailey, John Biggs, Hugh Platt, Elizabeth Shore, and Jack Tinker who gave us permission to survey their regions; Julie DeSimon who coordinated the fieldwork; and Dr R C King who inspired these projects. We also thank Julian Lipscombe for entering data.

1 Calman KC. The preregistration year. In: Downie RS, Charlton B, eds. The making of a doctor: medical education in theory and practice. Oxford: Oxford University Press, 1992.

2 McManus IC, Lockwood DNJ, Cruickshank JK. The preregistration year: chaos by consensus. Lancet 1977; i:413-6.

3 Christie RAS. The preregistration house appointment: a survey in Manchester. Med Educ 1980;14:210-3.
4 Dent THS, Gillard JH, Aarons EJ, Crimlisk HL, Smyth-Pigott PJ. Preregistration house officers in the four Thames regions. I. Survey of education and workload. $B M Y$ 1990;300:713-6.

5 General Medical Council. Recommendations on general clinical training. London: GMC, 1992.

6 University of London. The preregistration year: inappropriate duties for preregistration house officers. London: University of London, 1990.

7 Gillard JH, Dent THS, Aarons EJ, Crimlisk HL, Smyth-Pigott PJ, Nicholls $M W N$. Preregistration house officers in the Thames regions: changes in quality of training after four years. $B M F$ 1993;307:1176-9.

8 NHS Management Executive. Doctors and dentists in training: terms and conditions of service/model contract guidance (HSG (93) 1). London: NHSME 1993.

9 General Medical Council. Recommendations on general clinical training. London: GMC, 1987.

10 Richards $P$. Educational improvement of the preregistration period of general clinical training. $B M 7$ 1992;304:625-7.

11 Morris F, Tordoff SG, Wallis D, Skinner DV. Cardiopulmonary resuscitation skills of preregistration house officers: five years on. $B M \mathcal{F}$ 1991;302:626-7.

12 Wilson DH. Education and training of preregistration house officers: the consultants' viewpoint. $B M^{\mathcal{F}}$ 1993;306:194-6.

13 Dowling S, Barrett S. Doctors in the making: the experience of the preregistration year. Bristol: School for Advanced Urban Studies, 1992

14 Grant J, Marsden P, King RC. Senior house officers and their training. I Personal characteristics and professional circumstances. II. Perceptions of service and training. $B M 7$ 1989;299:1263-8.

15 Lowry S. The preregistration year. BMf 1993;306:196-8.

16 Vassallo DJ, Chana J, Clark CL, Smith RE, Wood RF. Introduction of a partial shift system for house officers in a teaching hospital. $B M$ 1992;305:1005-8.

17 Nasmyth DG, Pickersgill A, Hogarth M. Reducing hours of work of

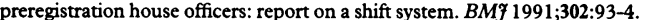

18 University of London. House of work-the preregistration year. London: University of London, 1993.

19 Denton M, Morgan MS, White RR. Quality of prescribing of intravenous antibiotics in a district general hospital. $B M \mathcal{F} 1991 ; 302: 327-8$.

20 Dowie R. Patterns of hospital medical staffing: overview. London: HMSO, 1991

21 Dowie R. Patterns of hospital medical staffing: overview. London: HMSO, 1991. 1992;48:215-7.

(Accepted 8 September 1993)

\title{
Heterosexual transmission of HIV in injecting drug users
}

\section{Edinburgh Drug Addiction Study, Edinburgh EH4 4PL Peter J M Ronald, research associate \\ J R Robertson, general practitioner}

\section{MRC Heterosexual}

Transmission Study,

Edinburgh EH4 4PL

$\mathrm{R}$ Wyld, research nurse

$\mathrm{R}$ Weightman, research nurse

Correspondence to:

Dr Robertson.

BMF 1993;307:1184-5

Annual incidence of HIV infection among 440 injecting drug users from 1982 to 1993

\begin{tabular}{ccc}
\hline & \multicolumn{2}{c}{$\begin{array}{c}\text { No of seroconversions } \\
\text { attributed to: }\end{array}$} \\
\cline { 2 - 3 } & $\begin{array}{c}\text { Shared } \\
\text { injecting }\end{array}$ & $\begin{array}{c}\text { Heterosexual } \\
\text { intercourse }\end{array}$ \\
\hline Year & equipment & 0 \\
1982 & 0 & 0 \\
1983 & 76 & 0 \\
1984 & 49 & 0 \\
1985 & 30 & 0 \\
1986 & 9 & 0 \\
1987 & 0 & 3 \\
1988 & 0 & 2 \\
1989 & 0 & 0 \\
1990 & 0 & 0 \\
1991 & 0 & 0 \\
1992 & 0 & 2 \\
1993 & 0 & 1 \\
\hline Total & 164 & 8 \\
\hline
\end{tabular}

\section{Peter J M Ronald, J R Robertson, R Wyld, R Weightman}

The rapid rise in the prevalence of HIV infection among injecting drug users during the early 1980 s in Edinburgh was attributed to sharing injecting equipment. ${ }^{1}$ More recently injecting drug users in Edinburgh and other British cities have reduced their high risk behaviour, ${ }^{23}$ probably because of increased awareness of the risks of infection. We investigated whether seroconversion attributable to injecting behaviour had also declined in this population since the mid-1980s.

\section{Subjects, methods, and results}

In a longitudinal study of 440 injecting drug users 172 (119 men) were positive for HIV antibodies and 148 (104 men) were negative; 120 (86 men) were not tested for various reasons. Dates of seroconversion were estimated for the 172 infected subjects as the midpoint between the dates of the last test giving negative results for HIV antibodies and the first giving positive results. If the date of the last negative test was unknown we used 1 January 1983, which has been calculated as the first possible date that HIV could have been transmitted in Edinburgh. ${ }^{4}$ Seroconversion was attributed either to sharing infected injecting equipment or to heterosexual intercourse between injecting drug users. The mode of transmission was determined from self reported data obtained during follow up, from medical records, and from medical staff concerned with the patients' care.

The table shows that the incidence of HIV infection attributable to sharing injecting equipment reached a peak in 1983 but then declined rapidly. From 1987 none of the eight seroconversions was attributable to sharing injecting equipment: all were attributable to unprotected heterosexual intercourse.

\section{Comment}

Although the annual incidence of HIV among injecting drug users has been low since 1987, it represents the emerging problem of heterosexual transmission of HIV. These rates probably underestimate the true incidence of sexually transmitted HIV infection for injecting drug users because we have not followed up any of their heterosexual contacts who do not inject drugs. There are virtually no recorded homosexual relationships in this group.

In the early ' 80 s attention was focused on transmission of HIV by sharing injecting equipment. Transmission among injecting drug users who admitted sharing may have been attributed solely to drug use without considering heterosexual intercourse as an alternative cause. The uncertainty surrounding this issue is compounded by the reliance on self reported information.

Despite national and local campaigns to educate the public about the risks of unprotected heterosexual intercourse the regular use of condoms remains low. Even those couples at highest risk because one partner is positive for HIV often continue to have unprotected sex, possibly often with a view to achieving pregnancy ( $\mathrm{R}$ Wyld et al, seventh international conference on AIDS, Florence, 1991). People generally seem unconvinced about the risks of heterosexual transmission. They receive conflicting messages, and information campaigns are undermined as members of the public increasingly gain personal experience of couples who do not practise safe sex without transmitting HIV.

HIV has already been transmitted to the next generation in the United Kingdom. ${ }^{5}$ In Scotland most heterosexual transmission has occurred among sexual contacts of injecting drug users. If an epidemic of HIV 
in the heterosexual population is to be prevented intervention should focus primarily on injecting drug users and their partners who continue to engage in unprotected heterosexual intercourse.

Since this paper was prepared a number of seroconversions attributed to needle sharing have occurred in a Scottish prison. At least one of our group is involved.

This study is funded by the Medical Research Council.
1 Robertson JR, Bucknall ABV, Welsby PD, Roberts JJ, Inglis JM, Peutherer F, et al. Epidemic of AIDS related virus (HTLV-111/LAV) infection among intravenous drug abusers. BMF 1986;292:527-9.

2 Ronald PJM, Robertson JR, Roberts JJK. Risk taking behaviour on the decline in intravenous drug users. Br $\mathcal{F}$ Addict 1992;87:115-6.

3 Donoghoe MC, Stimson GV, Dolan KA. Syringe exchange in England: an overview. London: Tufnell Press, 1992.

4 Robertson JR. The Edinburgh epidemic: a case study. In: Strang J, Stimson G, eds. AIDS and drug misuse. London: Routledge, 1990.

5 Johnson AM. Home grown heterosexually acquired HIV infection. $B M \mathfrak{F}$ 1992;304:1125-6.

(Accepted 13 fuly 1993)

\section{Postmarketing study of cardiovascular adverse reactions associated with sumatriptan}

\section{J P Ottervanger, T B van Witsen, H A Valkenburg, B H Ch Stricker}

\section{Netherlands Centre for Monitoring of Adverse Reactions to Drugs, PO Box 5406, 2280 HK Rijswijk, Netherlands J P Ottervanger, medical officer \\ B H Ch Stricker, principal medical officer}

\section{University Centre of} Pharmacy, Section of Social Pharmacy, University of Groningen, Groningen, Netherlands T B van Witsen, research assistant

\section{Department of Epidemiology and} Biostatistics, Erasmus University Medical School, Rotterdam, Netherlands H A Valkenburg, professor

Correspondence to: Dr Stricker.

BMF 1993;307:1185

Prevalence of cardiovascular adverse reactions associated with sumatriptan in 1727 patients

\begin{tabular}{lc}
\hline $\begin{array}{l}\text { Adverse } \\
\text { reaction }\end{array}$ & No (\%) of patients \\
\hline Chest pain & $23(1 \cdot 3)$ \\
Palpitations & $6(0.35)$ \\
Hypertension & $2(0.12)$ \\
Syncope & $2(0.12)$ \\
Bradycardia & $1(0.06)^{\star}$ \\
\hline
\end{tabular}

*Also developed chest pain.
In May 1991 the serotonin-1 agonist sumatriptan was registered in the Netherlands for the treatment of acute attacks of migraine and cluster headache. In clinical trials sensations of pressure and tightness in the chest were experienced by $3 \%$ to $5 \%$ of patients, but no electrocardiographic evidence of cardiac ischaemia was found. ${ }^{1}$ Since being marketed sumatriptan has been associated with pain like angina pectoris ${ }^{2}$ and, when given subcutaneously, with chest pain accompanied by ST elevation in an electrocardiogram ${ }^{3}$ and with acute myocardial infarction in a previously healthy young women. ${ }^{4}$ We conducted a postmarketing study of the prevalence of cardiovascular adverse reactions associated with sumatriptan in cooperation with dispensing general practitioners.

\section{Patients, methods, and results}

In July 1992 all 687 dispensing general practitioners in the Netherlands were asked to provide the date of birth and sex of every person to whom sumatriptan had been dispensed since it was marketed in May 1991. They were also asked about the route of administration and whether they had observed any adverse reactions in their patients. To avoid bias no specific adverse reactions were mentioned in the questionnaire. The non-responders received two reminders, 11 and 17 weeks after the first request. Information was entered into a database and results were analysed by using two tailed $\chi^{2}$ and Student's $t$ tests.

The request yielded a response rate of $86 \%$ ( 589 general practitioners). Of these, 474 had dispensed sumatriptan on at least one occasion to a total of 1727 patients (414 men (24\%) and 1313 women (76\%)). Of the 1662 patients (96\%) with information about the route of administration, $683(41 \%)$ had taken sumatriptan orally, $842(51 \%)$ subcutaneously, and $137(8 \%)$ both orally and subcutaneously.

Of the 1727 patients, 185 (10.7\% (95\% confidence interval $9 \cdot 3 \%$ to $12 \cdot 1 \%$ )) had reported one or more adverse reactions, which resulted in a total of 247 adverse reactions. The mean age of the 1542 patients who did not report any adverse reactions was 43.8 (SD $11 \cdot 2)$, and $1172(76 \%)$ were women. The mean age of the 185 patients who reported adverse reactions was $43.3(11 \cdot 2)$, and $141(76 \%)$ were women. The most frequently reported adverse reactions were dizziness, nausea or vomiting, drowsiness or sedation, and chest pain, which were reported in $30,26,25$, and 23 patients respectively. Of the 183 patients who reported an adverse reaction and for whom date on administration were known, 81 (44\%) had been given sumatriptan The mean age of the patients was $43 \cdot 8$ years (SD 11.2). orally, $77(42 \%)$ subcutaneously, and 25 (14\%) both orally and subcutaneously. The corresponding figures for those who did not report any adverse reaction were $602(41 \%), 765(52 \%)$, and $112(8 \%)\left(\chi^{2}=10 \cdot 82, \mathrm{df}=2\right.$, $\mathrm{p}=0.004)$.

The table summarises the cardiovascular adverse reactions. Chest pain was reported by $19(83 \%)$ women and four $(17 \%)$ men, of whom eight (35\%) had taken sumatriptan orally, 11 (48\%) subcutaneously, and four $(2 \%)$ both orally and subcutaneously. The mean age of these patients was $44 \cdot 0(6 \cdot 4)$ years. Of the 1704 patients who did not report chest pain and for whom data on administration were known, 675 (41\%) had taken sumatriptan orally, $831(51 \%)$ subcutaneously, and $133(8 \%)$ ( $\chi^{2}$ with Yates's correction $\left.=2 \cdot 6, p=0 \cdot 27\right)$. Their mean age (43.8 (11.3) years) and the proportion of men and women $(410(24 \%)$ and $1294(76 \%)$ respectively) were not significantly different from the values in the group reporting chest pain. The prevalence of chest pain associated with sumatriptan was $1 \cdot 3 \%$ (95\% confidence interval $1 \cdot 2 \%$ to $1 \cdot 5 \%$ ).

\section{Comment}

Reports of angina pectoris and acute myocardial infarction with sumatriptan prompted us to estimate the prevalence of chest pain with this drug under everyday conditions. Dispensing general practitioners are a good source of information on adverse reactions to newly marketed drugs because of their excellent cooperation and direct access to data on dispensed drugs and disease in individual patients.

We intend to send a questionnaire to all patients who were treated with sumatriptan to investigate whether unreported adverse reactions occurred because the prevalence of chest pain in our study was lower than that in clinical studies. ${ }^{1}$ For an adverse reaction to be recognised, however, patients have to tell their general practitioner. If they fail to do so the prevalence of adverse reactions will be underestimated when reactions are mild.

A recent angiographic study suggested that sumatriptan causes coronary artery vasoconstriction. ${ }^{5}$ That chest pain was observed both in our study and in similar reports ${ }^{2}$ highlights the need for an extensive study, especially given the reported electrocardiographic abnormalities ${ }^{3}$ and myocardial infarction ${ }^{4}$ with sumatriptan. We therefore intend to set up a casecontrol study of patients with self reported chest pain to assess determinants of this adverse reaction.

We thank the dispensing general practitioners for their cooperation in this study.

1 Brown EG, Endersby CA, Smith RN, Talbot JCC. The safety and tolerability of sumatriptan: an overview. Eur Neurol 1991;31:339-44.

2 Stricker BHC. Coronary vasospasm and sumatriptan. BMF 1992;305:118.

3 Willet F, Curzen N, Adams J, Armitage $M$. Coronary vasospasm induced by subcutaneous sumatriptan. $B M F$ 1992:304:1415.

4 Ottervanger JP, Paalman HJA, Boxma GL, Stricker BHCh. Transmural myocardial infarction with sumatriptan. Lancet 1993;341:861-2.

5 Macintyre PD, Bhargava B, Hogg KJ, Gemmill JD, Hillis WS. Effect of subcutaneous sumatriptan, a selective $5 \mathrm{HT} 1$ agonist, on the systemic, pulmonary, and coronary circulation. Circulation 1993;87:401-5.

(Accepted 8 fuly 1993) 